\title{
Sustainable Curbing of Youth Restiveness In IMO State: The Strategic Role Of Entrepreneurship Development
}

\author{
Prof. Gideon A. Emerole \\ Department of Business Administration \\ Michael Okpara University of Agriculture, Umudike, Abia State \\ Goddey C. Chikwe \\ Department of Business Management \\ Evangel University, Akaeze, Ebonyi State \\ Augustus-Daddie Joel \\ Department of Business Administration and Management \\ Ken Saro-Wiwa Polytechnic, Bori, Rivers State
}

\begin{abstract}
This study examined Curbing Youth Restiveness in Imo State: The Strategic Role of Entrepreneurship Development. The descriptive survey research method was adopted and the study covered a population of 1396 people randomly selected from 20 autonomous communities from the two oil bearing Local Government Areas in Imo state, representatives of community based Non-governmental organizations that are involved in youth capacity development, security experts and scholars of sociology and rural development. Data was generated through a five point likert scale questionnaire from a sample of 311 respondents chosen using the Taro Yamene method. The hypotheses were tested with kruskawalis test $(\mathrm{H})$ with the aid of the 23.0 version of statistical package for social sciences (SPSS) based on the 279 questionnaires validly filled and returned. The study concluded that the fight against youth restiveness and indeed all social vices in Imo state in particular and Nigeria at large must be reorganized to adopt proactive and preventive measures through the expansion of the nation's economic space for youth's inclusiveness, especially youths in rural areas whose access to functional and quality education is very limited. This can only be achieved if entrepreneurial development is giving active attention and not mere lip service. Furthermore, a comparative look at the results obtained (i.e EKCD 0.001 and AF 0.002) shows that sharing money to youths without giving them functional entrepreneurial skills does not create the needed sustainable route to curbing restiveness. It was recommended that to curb restiveness, youths empowerment should focus more on entrepreneurial knowledge creation and sharing than sharing of funds without tagging them to productive economic projects, school curriculum should be revised to embrace entrepreneurship development and that attention should be giving to vocational education through the establishment and adequate funding of vocational institutions that equips the youths with contemporary marketable entrepreneurial skills
\end{abstract}

KEYWORDS: Access to Finance, Entrepreneurial, Knowledge creation, Sustainable

\section{INTRODUCTION}

Youth restiveness in Nigeria has been a predominant issue in recent past. Increase in the occurrence of acts of violence and lawlessness, including things like hostage taking of prominent citizens and expatriate oil workers, as well as oil bunkering, arms insurgence, cultism, etc is gradually returning as a norm especially in the Niger Delta region. History has shown that youth restiveness is not a recent phenomenon. Various forms of youth restiveness that are economically, politically, or religiously motivated have existed for a long time. 
Elegbeleye (2005) vividly captures the presence and effects of youth restiveness in Nigeria when he stated that young people all over the world are vital and important segment of the society in which they live. A disciplined, focused, and law abiding youth can create a bright future for any nation. Conversely, a lawless, indulgent, and violent youth is a great threat to a nation's peace and security. It is important to note that in a nation like Nigeria, there appears to be a disconnect between the youths and the government which has pushed many youths to self-help which includes civil disobedience that manifest in their indulgence into actions that are inimical to the society and that constitutes sabotage to the economy of the nation. However, over the years, the different state governments in the Niger Delta region through their ministry of youth development and other social interventionist institutions and programmes have sought for economic models that can guarantee the active inclusion of the youths in the economy while helping to mitigate security challenges. One of such economic model/measure is the promotion of entrepreneurship among the youths.

In Imo state, the approach to managing youth militancy has taking an inglorious political face than a sustainable model. The creation of multiple youth organizations such as Niger Delta Youths Movement (NDYM), Imo State Oil Producing Area Commission Youths (ISOPADEC YOUTHS) and other community based youth organizations under the sponsorship of either the state or local government ares etc and the foisting of politically manipulated leadership on these youth organizations by the community leaders who are cronies or representatives of the government has not help matters rather it has exacerbated the acrimony among the youths which often takes its toll on the security of the communities and the dignity of the youths and human race. Furthermore, the state government has joined the bandwagon by failing to institutionalize a comprehensive model for curbing this menace rather, they have consistently engaged in face saving measures; for example, in the year 2013, the Imo State government purportedly distributed the sum of one five hundred million naira to the youths of Oguta and Ohaji/Egbema local government areas which are the two oil bearing local governments in Imo state which it tagged "Youth Empowerment Trust Fund", the governor stressed that the essence is to address the restiveness occasioned by poverty and lack of job in the areas (source; News Express 12/07/2013). Five years down the line, the narratives as it affects real youth's empowerment have not changed for good rather it has worsened and the purported trust fund eroded. While politicians clapped and promoted this waste of our common patrimony as youth empowerment, the impact of this on the curbing of social vices among the youths is yet to be seen. Similar to this is the appointment of youths who are believed to have links to this restive youth groups into government as a palliative measure to assuage them, while this may have recorded marginal success in helping to promote peace in these oil bearing communities, its sustainability is highly questionable, hence its failure as a route to curbing the restiveness among the youths. It has therefore become pertinent to look towards a more reliable and sustainable model that can prepare the youths with skills for tomorrow, give them hope in place of despair, restore their dignity, self confidence and integrity as responsible and responsive members of the society.

\section{Objectives of the study}

This study is generally focused on Curbing Youth Restiveness in Imo State: the Strategic Role of Entrepreneurship Development, its specific objectives are

i. Examination of entrepreneurial knowledge creation and diffusion as a model for curbing youth restiveness in Imo state

ii. Examination of access to finance as model for curbing youth restiveness in Imo state 


\section{Hypotheses}

$\mathbf{H}_{01}$ : Entrepreneurial knowledge creation and diffusion is not a significant model for curbing youth restiveness in Imo state

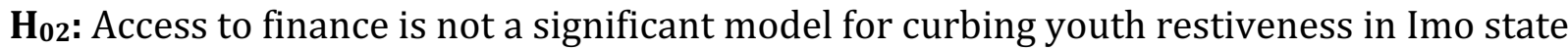

\section{REVIEW OF LITERATURES}

The National Youth Development Policy (2001) defines youth as people aged 18-35. The total population of youths between 10 and 24years in Nigeria was 45.4 million in 2006, which is 34 percent of the total population. Young people constitute the majority of the population and are at the centre of societal interactions and transformations. Yet, children and youths are often placed at the margins of the public sphere and major political, socio-economic and cultural processes. According to Ikelegbe, youth ordinarily is a category of early adulthood, emerging in activity and involvement in society but somewhat limited by societal values and some levels of dependency and perhaps agency (Ikelegbe, 2006). Elegbeleye (2005) defined youth restiveness as "a sustained protestation embarked upon to enforce desired outcome from a constituted authority by an organized body of youths." It is marked by violence and disruption of lawful activities. Youth restiveness manifests through confrontation, vandalization of oil pipelines, oil bunkering, oil mafia, oil piracy, work stoppages, kidnapping of company staffs for ransom, extortion e.g. illegal levies from oil company workers etc. According to Komonibo (2004), this could be as a result of intra and inter community strife, poverty, protracted property disputes e.g. farm land, religious and ethnic divide economic marginalization, political marginalization and high handedness of office/political office holders, destruction of traditional values, dissatisfaction with government policies, drug abuse. Fubara (1996) identified collapse of the educational system, the economy, socio-political instability due to frequent and violet change of government, easy access to all kinds of deadly weapons as well as absence of acquisition of employable and entrepreneurial skills by the youths, lack of employment opportunities for the youths and social uprising in Nigeria as being responsible for youth restiveness in Niger Delta Region. He also identified missiles, rocks, firearms of all descriptions, crude guns, military artillery, dynamites, improvised explosive devices (IED) machetes, axes, and high powered engine boats etc., as the weapons at the disposal of the restive youths.

Entrepreneurship according to wikipedia, "is the act of being an entrepreneur" or "one who undertakes innovations, finance and business acumen in an effort to transform innovations into economic goods". This may result in new organizations or may be part of revitalizing mature organizations in response to a perceived opportunity. The most obvious form of entrepreneurship is that of starting new business which is referred to as 'Start-up Company'. Entrepreneurship has been simply captured as the use of human courage to seek investment opportunities and establish a profit-oriented enterprise (Ikeme \& Onu, 2007). Entrepreneurship is generally viewed as a process of creating something new. Doing this involves a lot of time and effort devoted to ensure the tasks at hand and the resultant effects include monetary and personal satisfaction as well as independence. Entrepreneurship involves creation process, conscious devotion of time and effort, involves risk and has some rewards. Gana (2001), defined it as willingness and ability of an individual to seek out investment opportunities in an environment and be able to establish and run an enterprise successfully based on identified opportunities. Hisrich and Peters (2002), simply captured the term as the dynamic process of creating incremental wealth. They went further to explain that entrepreneurship is the personalized version of actualizing one's desire, ambition, and expression. Entrepreneurship is the capacity to harness the right quantity, quality and combination of resources that are consistent with profit making under risks and uncertainty. Essien (2006), defined entrepreneurship as the totality of self-asserting attributes that enable 
a person to identify latent business opportunities, together with capacity to organize needed resources with which to profitably take advantage of such opportunities in the face of calculated risks and uncertainty

Ohaegbulem (2002) classified entrepreneurship into four categories. They are basic production, processing, distribution and services.

1. Basic Production: This includes farming, poultry, fishery, forestry, animal husbandry, etc. A veterinary medical doctor can set up a piggery or goatry. A botanist can go for tree plantation and agriculturist can go for yam, cassava, wheat, beans growing, etc.

2. Processing: This includes manufacturing, construction, food processing, publishing and printing, etc. The home economist can manufacture soap; bake different kinds of food from flour, knit sweater and cardigan. The educationist can open a model private commercial school.

3. Distribution: This includes wholesale and retail trading, advertising, transportation and some forms of communication businesses. Youths in Niger Delta can go into selling one commodity or the other, open supermarkets, business centres, etc.

4. Services: This includes finance, insurance, professional services such as secretarial and other reprographic functions. From the foregoing therefore, it could be concluded that various entrepreneurial skills exist. To this end, for any youth to function efficiently, there is need for him or her to acquire the needed entrepreneurial skills through the programme of study.

Youth occupy a prominent place in any society. Apart from being the owners and leaders of tomorrow, they outnumber the middle-aged and the aged (Onyekpe, 2007). Besides numerical superiority, youth have energy and ideas that are society's great potentials (Onyekpe, 2007). The National Youth Development Policy (2001,) asserts that Youth are the foundation of a society. Their energies, inventiveness, character and orientation define the pace of development and security of a nation. Through their creative talents and labour power, a nation makes giant strides in economic development and socio-political attainments. In their dreams and hopes, a nation founds her motivation; on their energies, she builds her vitality and purpose. And because of their dreams and aspirations, the future of a nation is assured. The statement above acknowledges the role of the youth in the peace and security of a nation. As the most active segment of any society, youth are the major determiners of peace and stability of a nation (Ozohu-Sulaiman, 2006). Conversely, the degree of disorderliness and instability in society is also determined in part by youth. Peace is a precursor of development. The absence of peace means that no meaningful development can take place. The National Youth Policy (2001) affirms that the extent of the youth's "responsible conduct and roles in society is positively correlated with the development of their country".

\section{YOUTH RESTIVENESS: CAUSES AND CONSEQUENCES}

A number of studies have identified factors responsible for youth restiveness. Elegbeleye (2005) identifies three major factors: the peer motivated excitement of being a student, the jingoistic pursuit of patriotic ideas, and perceived victimization arising from economic exploitation. Another study carried out in Niger Delta region by Ofem and Ajayi (2008) identified lack of humanitarian and social welfare, lack of good governance, corrupt practices of government officials, inadequate training programmes, unemployment, inadequate recreational facilities, lack of quality education, and so on, as the reasons for incessant youth restiveness. This implies that a catalogue of closely-related factors is responsible for youth restiveness. 
$>$ Bad Governance: Good governance is required for the growth and development of any nation. Unfortunately, in Nigeria bad governance is more common than good, resulting in disjointed development. The World Bank (1992) identifies the main characteristics of bad governance to include:

- failure to properly distinguish between what is public and what is private, leading to private appropriation of otherwise public resources;

- inability to establish a predictable frame work for law and government behaviour in a manner conducive to development, or arbitrariness in the application of laws and rules;

- excessive rules, regulations, licensing requirement and so forth which impede the functioning of markets and encourage rent-seeking;

- priorities that are inconsistent with development, thereby resulting in misallocation of national resources; and

- Exceedingly narrow base for, or non-transparent, decision making. These and more are the features of most administration in Nigeria. For instance, Onyekpe (2007) observes that successive administrations in Nigeria have not allocated much to the needs of the youth, and, worse still, the meager allocation are often diverted by government officials to their private accounts and projects. Thus, youth are restive and agitated when they perceive that resources meant for them are being wasted by those in authority.

> Unemployment: Unemployment is a hydra-headed monster which exists among the youth in all developing countries. Experts believe that the number of jobless youth is twice as high as official estimate. Ozohu-Suleiman (2006) notes Nigerian youth are trapped by unemployment. Zakaria (2006) believes that "the rising tide of unemployment and the fear of a bleak future among the youth in African countries have made them vulnerable to the manipulations of agents' provocateurs". These include aggrieved politicians, religious demagogues, and greedy multinationals that employ these youths to achieve their selfish ambitions. Zakaria (2006) strongly believes that the absence of job opportunities in developing countries is responsible for youth restiveness with disastrous consequences.

$>$ Poverty: Poverty connotes inequality and social injustice and this traumatizes the poor. More than 70 percent of people in Nigeria are in abject poverty, living below the poverty line, and one- third survive on less than US \$1 dollar a day (Zakaria, 2006). This figure includes an army of youth in urban centres in Nigeria who struggle to eke out a living by hawking chewing sticks, bottled water, handkerchiefs, belts, etc. The sales-perday and the profit margin on such goods are so small that they can hardly live above the poverty line. Disillusioned, frustrated, and dejected, they seek an opportunity to express their anger against the state. Aworawo (2000) and Zakaria (2006) agreed that there is a link among poverty, loss of livelihood, inequality, and youth restiveness as evidenced by the numerous violent protests against the wielders of power in Nigeria.

$>$ Inadequate Educational Opportunities and Resources: Quality education has a direct bearing on national prestige, greatness, and cohesion. The knowledge and skill that young people acquire help determine their degree of patriotism and contribution to national integration and progress. Between 2000 and 2004, about 30 percent of Nigerian youth between 10 and 24 were not enrolled in secondary school (Population Reference Bureau, 2006). Perhaps the prohibitive cost of acquiring education is responsible. The after effect of this situation is that thousands of young people roam the streets in cities in Nigeria. Those who manage to complete secondary school have no opportunities for tertiary education. Having being denied the chance to reach their potential, they are disorientated and readily available for antisocial actions (Onyekpe, 2007). Worse still, some who struggle to enroll in various educational institutions drop out due to lack of basic learning facilities. This situation is attributable to the dwindling 
resources of government at both federal and state levels as a result of an economic meltdown.

$>$ Lack of Basic Infrastructure: Most rural communities and urban slums in Nigeria have no access to potable water, health facilities, electricity, communication facilities, industries and commercial facilities, etc. Behind social unrest and youth restiveness in the country is the agitation for equitable distribution of resources.

$>$ Inadequate Communication and Information flow: Information is new ideas or knowledge extracted from the environment for human use with the aim of modifying behaviour, effecting changes, and enhancing efficiency in all human endeavors (Ajegbomogun, 2008). Information helps create enlightened and responsible citizens. Communication creates room for sharing information. It helps people express their thoughts and feelings, clarify problems, and consider alternative ways of coping or adapting to their situation. Such sharing promotes social cohesion. People must have access to communication facilities, to communicate with the people making the decisions that affect them. Sadly, rarely do people in Nigeria participate in decisionmaking processes on issues that affect their lives. Ifidon and Ahiauzu (2005), in their study of Niger Delta, revealed that inadequate communication and information flow is one factor responsible for youth restiveness in the area. Odili (2004) viewed violent restiveness as human acts that have different courses and motives, which are infinite. He went further to identify some of the causes of restiveness in Niger Delta as follows:

1. Paranoid personal disorder and damaged self-concept: This makes people to blame others or the perceived "enemy".

2. Personal prevention: This is to meet the wishes of the institution and through processes of culturisation they see victims as less human.

3. Personal gain: This is simply promotion, pay rises or as a means of attracting one's or group goal.

4. Felt-needs to protect a culture threatened at its root particularly in the face of disillusionment with established legal process.

6. Mineral deposits and location of oil well, wrongly or rightly.

7. Sudden separation of ethnic groups that have lived together and peacefully in one province.

\section{ENTREPRENEURSHIP DEVELOPMENT: A PANACEA TO YOUTH RESTIVENESS}

Ubah (2011) posits that Entrepreneurship will in addition to helping willing recipients to establish their own small-scale business or company after graduation, also help them to have the knowledge of how entrepreneurial firms operate. It will enable them to acquire the skill for innovation, creativity and opportunity recognition which are very essential for anyone entering the market. They will also learn the skills that are necessary for the various and changing challenges they face in their lifetime. Ubah suggests that in addition to these, entrepreneurship will be useful in curbing restiveness by:

- Enhancement of economic growth for the individual and the nation.

- Poverty alleviation.

- The solving of the problem of youth restiveness, cultism, arm robbery, vandalization of oil pipelines among others.

- Reducing of the issue of kidnapping and insecurity of life and property.

- Minimizing of human trafficking and prostitution.

- The reduction of the level of unemployment and

- The increase of income per capita. 
Entrepreneurship among youths thus assumed importance against the background of poverty, widespread unemployment and the need to shift the attention of the citizenry away from white collar jobs and government patronage.

\section{METHODOLOGY}

The descriptive survey research method was adopted in this study and it covered a population of 1396 people randomly selected from 20 autonomous communities from the two oil bearing Local Government Areas in Imo state, representatives of community based Non-governmental organizations that are involved in youth capacity development, security experts and scholars of sociology and rural development. Data was generated through a five point likert scale questionnaire from a sample of 311 respondents chosen using the Taro Yamene method. The hypotheses were tested with kruskawalis test $(\mathrm{H})$ with the aid of the 23.0 version of statistical package for social sciences (SPSS) based on the 279 questionnaires validly filled and returned

SPSS OUTPUT FOR HYPOTHESIS ONE

NPAR TESTS / K-W=KCDandYR BY RANKS ( 15 )

/STATISTICS DESCRIPTIVES QUARTILES

/MISSING ANALYSIS.

\begin{tabular}{|c|c|c|c|c|c|c|c|c|}
\hline & \multirow[b]{2}{*}{$\mathrm{N}$} & \multirow[b]{2}{*}{ Mean } & \multirow[b]{2}{*}{ Std. Deviation } & \multirow[b]{2}{*}{ Minimum } & \multirow[b]{2}{*}{ Maximum } & \multicolumn{3}{|c|}{ Percentiles } \\
\hline & & & & & & 25 th & 50th (Median) & 75th \\
\hline $\begin{array}{l}\text { EKCDandYR } \\
\text { RANKS }\end{array}$ & $\begin{array}{l}25 \\
25\end{array}$ & $\begin{array}{r}55.0800 \\
3.0000\end{array}$ & $\begin{array}{r}38.87900 \\
1.44338\end{array}$ & $\begin{array}{r}.00 \\
1.00\end{array}$ & $\begin{array}{r}134.00 \\
5.00\end{array}$ & $\begin{array}{r}33.0000 \\
2.0000\end{array}$ & $\begin{array}{r}49.0000 \\
3.0000\end{array}$ & $\begin{array}{r}71.0000 \\
4.0000\end{array}$ \\
\hline
\end{tabular}

Kruskal-Wallis Test

Ranks

\begin{tabular}{|l|l|r|r|}
\hline & RANKS & N & Mean Rank \\
\hline EKCDandYR & 1.00 & 5 & 3.00 \\
& 2.00 & 5 & 14.00 \\
& 3.00 & 5 & 10.80 \\
4.00 & 5 & 23.00 \\
& 5.00 & 5 & 14.20 \\
& Total & 25 & \\
\hline
\end{tabular}

Test Statistics ${ }^{\mathrm{a}, \mathrm{b}}$

\begin{tabular}{|l|r|}
\hline & KCDandCYR \\
\hline Chi-Square & 19.163 \\
Df & 4 \\
Asymp. Sig. & .001 \\
\hline
\end{tabular}

a. Kruskal Wallis Test

b. Grouping Variable:

RANKS

At Asymp. Sig of 0.001 , the SPSS outcome above shows a positive significant interaction between entrepreneurial knowledge creation and dissemination and the curbing of youths' restiveness. The alternate hypothesis was therefore accepted in place of the null. This simply implies that entrepreneurial knowledge creation and diffusion can be leveraged extensively as a strategy to curb youth restiveness in Imo state

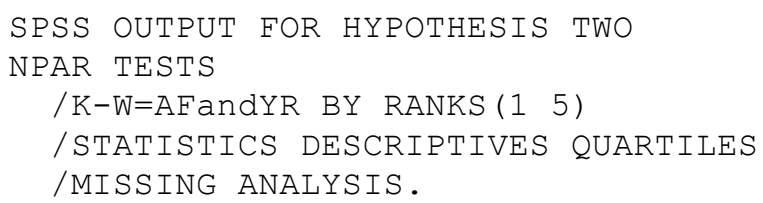


Descriptive Statistics

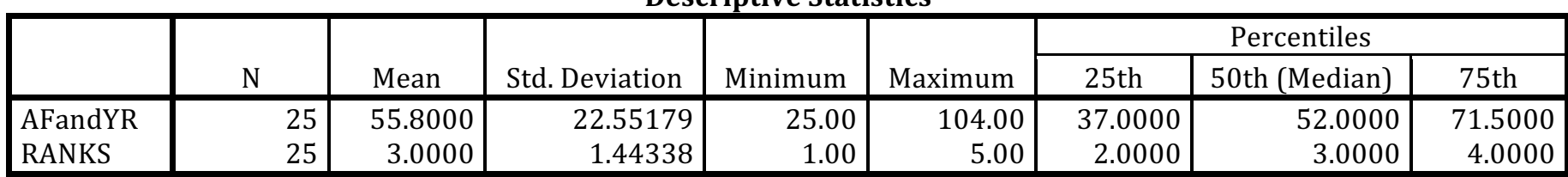

\section{Kruskal-Wallis Test}

Ranks

\begin{tabular}{|l|l|r|r|}
\hline & RANKS & N & Mean Rank \\
\hline AFandYR & 1.00 & 5 & 7.00 \\
& 2.00 & 5 & 19.70 \\
3.00 & 5 & 9.20 \\
4.00 & 5 & 21.00 \\
5.00 & 5 & 8.10 \\
Total & 25 & \\
\hline
\end{tabular}

Test Statistics,

\begin{tabular}{|l|r|}
\hline & AFandYR \\
\hline Chi-Square & 16.937 \\
Df & 4 \\
Asymp. Sig. & .002 \\
\hline
\end{tabular}

a. Kruskal Wallis Test

b. Grouping Variable:

RANKS

The SPSS output above puts the Asymp. Sig at 0.002, this suggests a significant positive interaction between access to finance and the curbing of youth restiveness in Imo State. This simply implies that access to finance plays strategic role to curbing youth restiveness in Imo state

\section{CONCLUSION}

This study concluded that the fight against youth restiveness and indeed all social vices in Imo state in particular and Nigeria at large must be reorganized to adopt proactive and preventive measures through the expansion of the nation's economic space for youth's inclusiveness, especially youths in rural areas whose access to functional and quality education is very limited. This can only be achieved if entrepreneurial development is giving active attention and not mere lip service. Furthermore, the a comparative look at the results obtained (i.e EKCD 0.001 and AF 0.002) shows that sharing money to youths without giving them functional entrepreneurial skills does not create the needed sustainable route to curbing restiveness

The study recommends as follows;

\section{RECOMMENDATIONS}

i. To curb restiveness, youths empowerment should focus more on entrepreneurial knowledge creation and sharing than sharing of funds without tagging them to productive economic projects

ii. School curriculum should be revised to embrace entrepreneurship development

iii. Attention should be giving to vocational education through the establishment and adequate funding of vocational institutions that equips the youths with contemporary marketable entrepreneurial skills

\section{References}

Ajegbomogun, F.O. (2008). Information availability and the extent of use in public library, Abeokuta. Borno Library, Archival, and Information Science Journal 7 (1): 65-74. 
Amorawo, D. (2000). Mal-distribution and poverty as factors in the crisis of the Nigeria state. The Constitution: A Journal of Constitutional Development 1 (2): 1-13.

Elegbeleye, O.S. (2005). Recreational facilities in schools: A panacea for youths' restiveness. Journal of Human Ecology 18 (2): 93-98.

Federal Government of Nigeria (2001). National Youth Policy. Available:

http://www.thepresidency.gov.za/docs/policy/national_youth_policy.pdf

Fubara, B. A, (1999). Youth and entrepreneurship development: The Case of Rivers State. Port Harcourt: Government Press.

Gana, J.S. (2001). Entrepreneurship. Kaduna: Jofegan Associates.

Hirsrich, R.D. and Peter, M.P. (2002). Entrepreneurship. New York: McGraw Hill. http://enropa.en/legislation_summaries/education_trainingyouth/general_framework/n.

Ifidon, S.E., \& Ahiauzu, B. (2005). Information and conflict prevention in the Niger Delta Region of Nigeria. African Journal of Libraries, Archives, and Information Science 15 (2): 125-132.

Ikelegbe, A, (2005). "The Economy of Conflict in the Oil Rich Niger Delta Region of Nigeria”, Nordic Journal of African Studies, 14(2), 208-234.

Ikeme, A., and Onu, V.C. (2007). Creativity, Innovation and Entrepreneurship: Implications for Nigerian Youths and Government. Paper Presented at the Annual Conference of the Nigerian Psychological Association, University of Nigeria, Nsukka

Komonibo, F.N. (2004). Violence, restiveness and cultism: causes, prevention and management: The law and the political class in the society. Port Harcourt: Government Press.

News Express (2013). Imo Govt. launches N500m Youth Empowerment Trust Fund. http://newsexpressngr.com/news/detail.php?news=2228

Ofem, N.I., \& Ajayi A.R. (2008). Effects of youth empowerment strategies on conflict resolutions in the Niger Delta of Nigeria: Evidence from Cross River State. Journal of Agriculture and Rural Development 6 (1,2): $139-146$.

Odili P. (2004). Portrait of performance: Platform for progress. Port Harcourt: The communications Ltd.

Ohaegbulem, N. M (2002). A radical view of entrepreneurial context of business education curriculum in Nigeria, education system. In E. A. Aromolran (ed.), Book of readings in business education, 1(1), 263-272.

Omotayo, B.O. (2005). Women and conflict in the new information age: Virtual libraries to the rescue. A paper presented at the world Library and Information Congress: 71st IFLA General Conference and Council August 14th, 2005, Oslo, Norway.

Onyekpe, N. (2007). Managing youth at election. The Constitution: A Journal of Constitutional Development 7 (1): 76-87.

Ozohu-Suleiman, A. (2006). The Nigerian youth in contemporary political development: Relevance, challenges, and role expectation. The Constitution: A Journal of Constitutional Development 6 (4): 97-111.

Population Reference Bureau (2006). The World's youth 2006 data sheet. Available:

http://www.prb.org/pdf06/WorldsYouth2006Data Sheet.pdf

Sabaratnam, J.S. (1997). Planning the library of the future: The Singapore experience. IFLA Journal 23 (3): $97-202$.

Ubah, M.C. (2011). Towards Achieving Effective Entrepreneurship Education in Social Studies Teaching Interactive Agenda Through Information And Communication Technology (ICT). Journal of Economics and Environmental Education, Vol. 1 (1).

World Bank (1992). Governance and development. Washington, DC: International Bank for Reconstruction and Development.

Zakaria, Y. (2006). Youth, conflict, security, and development. Available:

http://www.realityofaid.org/roareport.php?table=roa2006\&id=6 